\title{
Dendrites of Neocortical Pyramidal Neurons: The Key to Understand Intellectual Disability
}

\author{
Alberto Granato $^{1}$ (D) $\cdot$ Adalberto Merighi $^{1}$ (iD
}

Received: 27 April 2021 / Accepted: 27 June 2021 / Published online: 3 July 2021

(c) The Author(s) 2021

\begin{abstract}
Pyramidal neurons (PNs) are the most abundant cells of the neocortex and display a vast dendritic tree, divided into basal and apical compartments. Morphological and functional anomalies of PN dendrites are at the basis of virtually all neurological and mental disorders, including intellectual disability. Here, we provide evidence that the cognitive deficits observed in different types of intellectual disability might be sustained by different parts of the PN dendritic tree, or by a dysregulation of their interaction.
\end{abstract}

Keywords Cerebral cortex $\cdot$ Down syndrome $\cdot$ Fetal alcohol $\cdot$ Calcium $\cdot$ Dendritic spike $\cdot$ Apical dendrite

Uno de los hechos mejor apreciados entonces fue la revelación de la existencia constante en la corteza cerebral de batracios, reptiles, aves y mamíferos, del corpúsculo piramidal, que osé llamar, con audacia de lenguaje de que hoy me avergüenzo un tanto, la célula psíquica.

One of the most appreciated facts

at that time was the revelation of the constant existence in the cerebral cortex of batrachians, reptiles, birds and mammals, of the pyramidal cell, which I dared to call, with the audacity of language of which today I am a bit ashamed, the psychic cell. Santiago Ramón y Cajal

The father of modern Neuroscience, Santiago Ramón y Cajal, postulated that neocortical pyramidal neurons (PNs) might play an outstanding role for the accomplishment of higher cognitive functions. He defined these cells, representing the vast majority of neocortical neurons, the "psychic cells" (Cajal 1917). Despite his feeling of shame, aimed at

Alberto Granato

alberto.granato@unito.it

1 Department of Veterinary Sciences, University of Turin, Largo Paolo Braccini 2, 10095 Grugliasco, TO, Italy counterbalancing the "audacity of language," after more than a century we have to recognize that, once again, the claim of the great Spanish scientist was substantially right. In recent years, it has been shown that PNs, despite their apparent morphological homogeneity, are specialized for different physiological/behavioral functions in different cortical areas and species (see, for review, Jacobs and Scheibel 2002; Elston 2003; Spruston 2008; Luebke 2017). Moreover, cortical areas composed of specialized pyramidal cells are characterized by unique connectivity and capacity, with size of the dendritic tree and number of spines increasing progressively from primary to higher order areas (Elston 2007). These regional specializations in pyramidal cell structure and circuit connectivity are important for hierarchical and/or distributed processing (Elston 2003, 2007; Elston and Fujita 2014). On the same line of reasoning, it can be assumed that a functional derangement of PNs is the pathophysiological basis of the cognitive deficit observed in intellectual disability (Granato and De Giorgio 2014).

Intellectual disability (ID), previously referred to as mental retardation, is classically defined as a neurodevelopmental disorder with IQ below 70, although more complex definitions, based on poor adaptive functioning and reduced daily life skills, have been provided by the DSM-5 (American Psychiatric Association 2013) and the American Association on Intellectual Developmental Disabilities (Shogren and Turnbull 2010).

The present point of view deals with the anomalies of neocortical PNs, as observed in experimental studies 
reproducing known causes of ID, as well as in the brains of affected human individuals. Given that dendritic alterations are considered among the most relevant anatomical and functional counterparts of ID (Kaufmann and Moser 2000) and owing to the great extension and geometric complexity of the dendritic arborizations of PNs, we shall focus primarily on dendritic anomalies. Some excellent reviews cover exhaustively the relationships between dendritic alterations and ID (Kaufmann and Moser 2000; Dierssen and Ramakers 2006; Quach et al. 2021). Our purpose is to provide mechanistic insights into how the disruption of PN dendritic function contributes to the genesis of ID, with a special emphasis on the role of the different parts of the dendritic tree.

\section{Dendrites of PNs}

PNs represent the majority of neocortical neurons and are distributed in all cortical layers except layer 1. Among PNs, the thick-tufted cells are the most thoroughly studied, provide the cortical output directed to subcortical structures, and can be found in the deep part of layer 5 [layer $5 \mathrm{~b}$ (Spruston 2008; Ramaswamy and Markram 2015)]. Thicktufted PNs are characterized by a prominent apical dendrite spanning all the way to the pial surface and terminating with a branching apical tuft, whose radium often equals (or exceeds) that of the basal dendrites (Fig. 1). Other classes of PNs are those of layer 2/3 (providing cortico-cortical associative and callosal projections) and those bearing a slender apical dendrite, mainly located in the superficial part of layer 5 (Krieger et al. 2017; see also Fig. 1 in Shepherd 2013). Modified PNs projecting to the thalamus and claustrum reside in layer 6 (Thomson 2010).

The prototypical PNs, the thick-tufted cells of layer 5, display geometric differences among the basal, oblique, and apical dendritic domains that are clearly recognizable at a first glance (see Fig. 1). In a seminal paper published exactly thirty years ago, Alan Larkman provided a rigorous formal description of such branching pattern differences, pointing out, for instance, that basal dendrites branching points are close to the cell body, whereas intermediate branches of the apical tuft are relatively longer than distal ones (Larkman 1991). It is well known that the dendritic geometry impinges upon the functional properties of neurons (Mainen and Sejnowski 1996). Furthermore, different parts of the dendritic tree of layer 5 PNs are potentially involved in the microcircuitry of different cortical layers. Therefore, it is conceivable that basal and apical dendrites contribute differently to the cortical machinery during physiological cognitive tasks.

Regarding the connections, the basal dendrites receive feedforward input from the receptor surfaces through the thalamic relay. The ascending input is thought to be conveyed

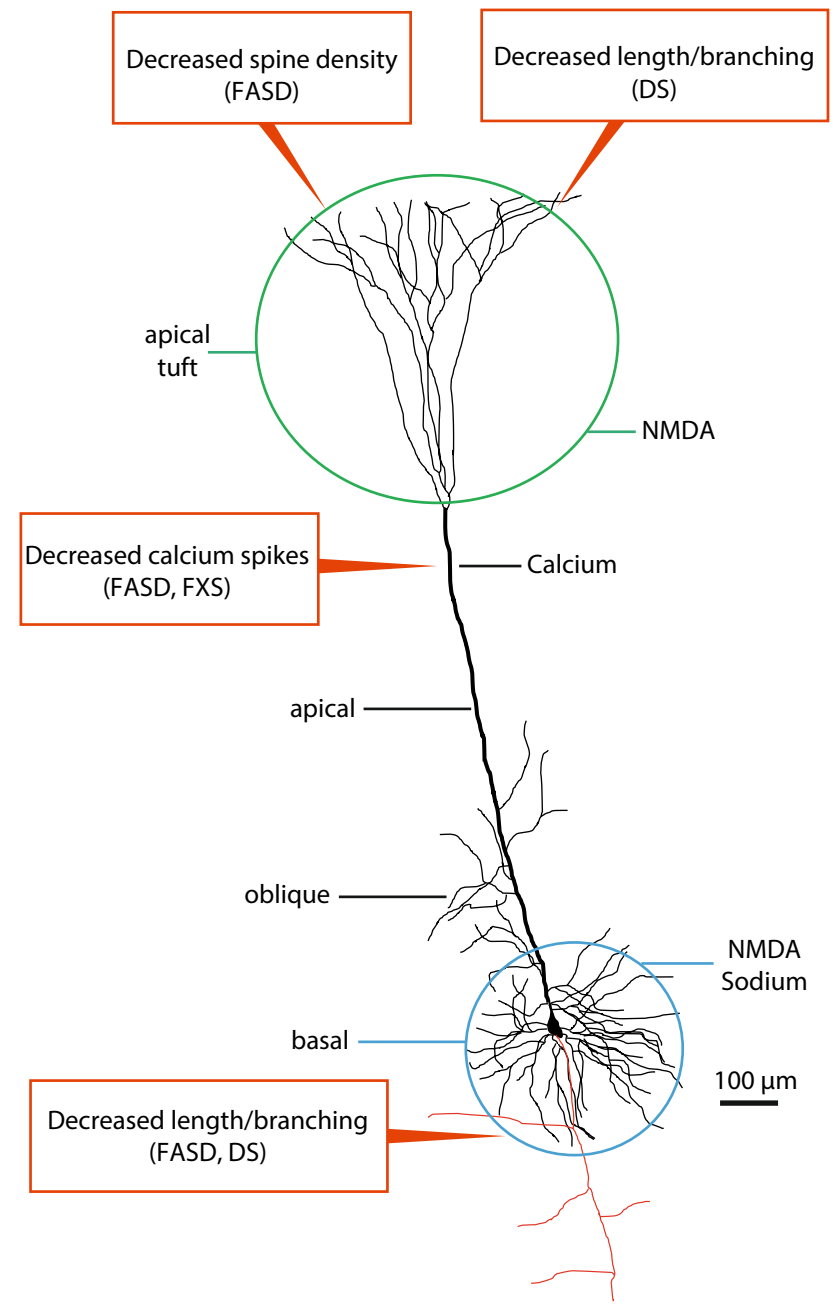

Fig. $13 \mathrm{D}$ reconstruction of a thick-tufted PN of layer 5. On the left of the neuron there is the indication of the different sections of the dendritic tree. On the right the main regenerative events occurring in that dendritic domain, according to Larkum et al. 2009. Red: axon. The text boxes indicate some of the alterations occurring in FASD, FXS, and DS, along with the dendritic domain affected (see the text for further explanation)

indirectly to the dendrites of layer 5 through the canonical cortical circuit [thalamus $\rightarrow$ layer $4 \rightarrow$ layer $2 / 3 \rightarrow$ layer 5 (Thomson and Morris 2002; Lübke and Feldmeyer 2007)]. However, layer 5 neurons can be also contacted directly by thalamic afferents (Meyer et al. 2010; Constantinople and Bruno 2013). Conversely, most of the apical tuft of PNs lies in layer 1, where it receives feedback connections from higher cortical areas, conveying input related to attention, context, and expectations (Coogan and Burkhalter 1990; Cauller 1995; Cauller et al. 1998). Together, the basal and apical dendritic arborization are in the ideal position to integrate bottom-up and top-down streams of information. The refinement of dendritic recording (Davie et al. 2006) made it possible to ascertain that action potentials can backpropagate 
through the apical dendrite of PNs (Stuart and Sakmann 1994) and to shed light on the interplay between basal and apical dendrites. Using multiple patch-clamp recordings from the soma and the apical dendrite of layer $5 \mathrm{PNs}$, it has been demonstrated that the coincidence of a backpropagated action potential generated at the soma and of an apical dendritic input is able to generate a dendritic calcium spike that, in turn, elicits a burst of somatic spikes (Larkum et al. 1999). This mechanism, originally called backpropagation-activated calcium spike firing (BAC firing) has been considered the electrophysiological basis of the top-down/ bottom-up integration operated by a single PN (Larkum 2013). This idea was widened by Bill Phillips and Matthew Larkum, leading to the concept of "apical amplification," the mean by which the information coming from the external world (bottom-up) is modulated by context-sensitive (topdown) information (Phillips et al. 2016; Phillips 2017). A role of the apical dendrite in cognition and consciousness has been also postulated by LaBerge (2006). Recently, it has been demonstrated that apical dendritic potentials can gate sensory perception and that such a modulation depends on contextual information (Takahashi et al. 2020). A dysregulation of context-modulated sensory perception and learning abilities can represent a prominent feature of ID (Alevriadou et al. 2004; Carr et al. 2010; Murray et al. 2019).

As to the distribution of ion channels on the membrane of different dendritic compartments, it has been proposed that the apical tuft and basal dendrites are dominated by NMDA receptors and associated potentials, while a calcium initiation zone, located just beneath the apical tuft, is endowed with voltage gated calcium channels (Nevian et al. 2007; Larkum et al. 2009); Fig. 1). Moreover, the correct degree of coupling between basal and apical compartments would be ensured by hyperpolarization-activated $\mathrm{HCN}$ channels, responsible for the Ih current and densely distributed on the apical dendrite of PNs (Nolan et al. 2004; Phillips et al. 2016). Interestingly, these ion channels are developmentally regulated (Atkinson and Williams 2009) and their dysregulation might be involved in the genesis of neurodevelopmental disorders (see below).

In the last years, a conspicuous line of research focused on the dual basal/apical organization of PNs. Changes in the apical amplification process have been implicated in the pathophysiology of several mental disorders, including schizophrenia (Phillips et al. 2016; Mäki-Marttunen et al. 2019). Furthermore, the integration of two different compartments with feedforward and feedback input seems to be ideally suited to bridge the gap between artificial intelligence and neuroscience, since there are similarities between deep learning algorithms and the functional subdivisions observed in PNs (Guerguiev et al. 2017).

Dendrites of pyramidal neurons are covered with spines, which receive most of synaptic inputs and are thought to play a central role in several functions, from electrical filter/ isolation to synaptic and structural plasticity (reviewed in Yuste 2011; Sala and Segal 2014). The density of dendritic spines, as well as their pattern of developmental growth and reshaping, display significant differences in different cortical areas (Elston and Defelipe 2002; Elston and Fujita 2014). Moreover, the density and distribution of dendritic spines appear to be differently regulated in apical and basal dendrites of PNs during learning (Knafo et al. 2001), in response to hormones (Gould et al. 1990), and in experimental models of neurological illness (Perez-Cruz et al. 2011).

\section{PN Dendritic Domains and ID}

From the features outlined above, it is clear that the extensive dendrites of neocortical PNs play a pivotal role in neural computation and higher functions. Therefore, the changes of PN dendrites appear to be central in the genesis of ID. Moreover, a disruption of the interplay between functionally distinct basal and apical compartments might contribute to the pathophysiology of several mental disorders, including ID. Here, we focus on PN dendritic alterations in some of the most frequently observed genetic and non-genetic types of ID. Among genetically determined IDs, Down syndrome (DS), caused by trisomy of the human chromosome 21 , besides representing the most commonly identified form (Sherman et al. 2007), can be also reproduced by murine models (Dierssen et al. 2001). Notably, dendritic alterations have been reported in both species (reviewed in Benavides-Piccione et al. 2004). Interestingly, when compared to matched-age controls, PNs in the visual cortex of individuals with DS showed a higher complexity of dendritic branching during the first six months of postnatal life, followed by a reduction of branches thereafter, and dendritic alterations were evident both in the apical and basal dendrites (Becker et al. 1986). In addition to these alterations in branching, a reduction of spine density has been reported in the apical dendrite of humans affected by DS (Suetsugu and Mehraein 1980). It should be noted, however, that PNs of the prefrontal cortex in a murine model of DS display an increased density of spines (Thomazeau et al. 2014). An augmented number of dysmorphogenetic dendritic spines is a consistent feature of a common inherited cause of ID, the fragile X syndrome (FXS), characterized by mutations of the FMRP, the protein encoded by the FMRl gene (Bagni and Greenough 2005).

The most common form of non-genetic ID is the consequence of the exposure to alcohol in utero and is nowadays referred to as fetal alcohol spectrum disorders (FASD). Rodent experimental models of FASD allowed to clarify several aspects in the pathogenesis of ID, including those related to PN dendritic anomalies (Valenzuela et al. 2012). 
Experimental FASD might represent an interesting case of dissociation between dendritic anomalies of basal and apical compartments: after exposure to ethanol during the first week of postnatal life in rats, corresponding to the third trimester of gestation in humans, the basal dendritic branches of PNs are strongly simplified, both in the somatosensory and in the prefrontal cortex (Granato et al. 2003, 2012; Hamilton et al. 2010). Conversely, the spine density of layer $2 / 3$ basal dendrites is not affected (Hamilton et al. 2010; De Giorgio and Granato 2015). Using the same experimental protocols, a specular alteration was observed in the apical dendrites, that featured normal branching properties along with a decreased spine density (Whitcher and Klintsova 2008; Granato et al. 2012; De Giorgio and Granato 2015). It is worth mentioning, however, that in other types of ID, such as congenital/neonatal hypothyroidism, the apical dendrite shows a modified branching pattern (Ipiña and RuizMarcos 1986).

\section{PN Dendrite Physiology and ID}

As noted above, active currents generated locally in the dendritic tree can play a fundamental role for the function of PNs. Disruption of dendritic potentials can be the signature of many neurological and mental disorders (Palmer 2014). In the experimental model of FASD, we have demonstrated that the generation of $\mathrm{Ca}^{2+}$ spikes in the apical dendrites of layer 5 PNs is strongly impaired (Granato et al. 2012). A derangement of dendritic $\mathrm{Ca}^{2+}$ signaling has been also reported in the murine model of FXS (Meredith et al. 2007) and might be part of a more complex set of dendritic channelopathies observed in this condition (Brager and Johnston 2014). Calcium spikes are required to induce synaptic plasticity (Kampa et al. 2006; Cichon and Gan 2015). In addition, they support the apical amplification mechanism described above, that in turn is thought to provide the neurobiological basis for context-sensitive perception and learning (Phillips 2017). Interestingly, shutting down the Ube3a protein leads to a selective defect of growth of PN apical dendrites (Miao et al. 2013). The deficiency of the Ube3a protein in humans is associated to the Angelman syndrome, a condition characterized by ID and whose murine model displays a deficit of contextual learning (Jiang et al. 1998). Besides a direct impairment of dendritic calcium electrogenesis, other factors can contribute to the anomalous function of the apical dendrite and to the genesis of ID. For instance, HCN channels, responsible for the Ih current, play a role in the interaction between the basal and the apical dendrites of PNs and some of their variants can be associated to ID (Marini et al. 2018). Another factor ensuring the communication between different dendritic compartments is represented by the backpropagation of axon potential along the apical dendrite.
Loss of sodium channels sustaining the backpropagation can also lead to ID (Spratt et al. 2019). Finally, PNs participate in a cortical microcircuit to which dendrite-targeting GABAergic interneurons provide a substantial contribution (Markram et al. 2004; Palmer et al. 2012; DeFelipe et al. 2013). Furthermore, top-down projections from higher cortical areas can engage in a disinhibitory circuit by contacting inhibitory neurons (chiefly VIP-calretinin cells) that, in turn, synapse onto other inhibitory cells, thus activating PN dendrites. Such a disinhibitory circuit might represent part of the neuronal basis for the apical amplification, since it is ideally suited to be involved in recalling past experiences and exploiting contextual cues (Pi et al. 2013; Karnani et al. 2014). Interestingly, an increase in the number of calretinin interneurons has been reported both in a model of FASD and in the Ts65Dn model of DS (Granato 2006; Pérez-Cremades et al. 2010).

The dendrites of each PN receive several thousand synapses. Therefore, although we focused on the morphofunctional dendritic alterations observed in the most representative ID syndromes, many rare mutations of synaptic proteins and ligand-gated ion channels can be responsible for anomalies of the dendritic machinery and can lead to ID (reviewed in Vieira et al. 2021). A striking example is represented by the mutations of the NMDA receptor subunits, whose consequence is represented either by loss or by gain of function, with possible excitotoxic mechanisms mediating the damage in the latter case (Lemke et al. 2016; Fry et al. 2018). NMDA mutations can also result in modified synaptic plasticity (Shin et al. 2020) and interference with dendritic growth (Sceniak et al. 2019).

\section{Concluding Remarks}

Considering that PNs are the most abundant neuronal type of the cerebral cortex, and that they bear a large dendritic tree, it turns out that PN dendrites occupy a considerable part of neocortical volume. Therefore, the primary role played by $\mathrm{PN}$ dendrites in cortical computation and their involvement in ID are quite obvious. Even though each ID syndrome seems to be characterized by a specific type of dendritic alteration, times are not yet mature to classify ID according, for instance, to the different dendritic domain primarily altered, to the spine density, or to the specific interplay between inhibitory interneurons and PN dendrites. Although such a classification might prove useful to steer the clinical and therapeutic interventions, any effort in this direction appears to be challenging. In fact, ID is a permanent condition that is usually established early during neural development, often through intermediate phases showing transient features (see, for example, the dendritic hypertrophy observed in DS). Furthermore, some of the pathologic 
features might merely represent a byproduct, or a compensation attempt, of primary alterations. This might be the case for the increased number of potentially disinhibitory interneurons observed in DS and FASD, or the increased density of dendritic spines in DS and FXS.

Studies on PN dendrites in humans affected by ID are shadowed by technical limitations, in particular, by the capricious Golgi staining. The refinement of recording and staining techniques, along with the increased possibility of modeling neurons and their dendrites, can help to improve the results of human investigations (Elston et al. 2001; Benavides-Piccione et al. 2013; Goriounova et al. 2018). Furthermore, animal models of ID allow detailed in vitro and in vivo explorations of dendrite and spine anomalies. Therefore, the collaboration among clinical, computational, and experimental neuroscientists will warrant a bright future for the research on ID and dendrites.

Author Contributions AG and AM conceived and wrote the manuscript.

Funding Open access funding provided by Università degli Studi di Torino within the CRUI-CARE Agreement.

\section{Declaration}

Conflict of interest The authors declare that there are no conflict of interest.

Open Access This article is licensed under a Creative Commons Attribution 4.0 International License, which permits use, sharing, adaptation, distribution and reproduction in any medium or format, as long as you give appropriate credit to the original author(s) and the source, provide a link to the Creative Commons licence, and indicate if changes were made. The images or other third party material in this article are included in the article's Creative Commons licence, unless indicated otherwise in a credit line to the material. If material is not included in the article's Creative Commons licence and your intended use is not permitted by statutory regulation or exceeds the permitted use, you will need to obtain permission directly from the copyright holder. To view a copy of this licence, visit http://creativecommons.org/licenses/by/4.0/.

\section{References}

Alevriadou A, Hatzinikolaou K, Tsakiridou H, Grouios G (2004) Field dependence-independence of normally developing and mentally retarded boys of low and upper/middle socioeconomic status. Percept Mot Skills 99(3 Pt 1):913-923. https://doi.org/10.2466/pms. 99.3.913-923

American Psychiatric Association (2013) Diagnostic and statistical manual of mental disorders, 5th edn. APA, Washington, DC

Atkinson SE, Williams SR (2009) Postnatal development of dendritic synaptic integration in rat neocortical pyramidal neurons. J Neurophysiol 102(2):735-751. https://doi.org/10.1152/jn.00083.2009

Bagni C, Greenough WT (2005) From mRNP trafficking to spine dysmorphogenesis: the roots of fragile $\mathrm{X}$ syndrome. Nat Rev Neurosci 6(5):376-387. https://doi.org/10.1038/nrn1667
Becker LE, Armstrong DL, Chan F (1986) Dendritic atrophy in children with Down's syndrome. Ann Neurol 20(4):520-526. https://doi. org/10.1002/ana.410200413

Benavides-Piccione R, Ballesteros-Yáñez I, de Lagrán MM, Elston G, Estivill X, Fillat C, Defelipe J, Dierssen M (2004) On dendrites in Down syndrome and DS murine models: a spiny way to learn. Prog Neurobiol 74(2):111-126. https://doi.org/10.1016/j.pneurobio.2004. 08.001

Benavides-Piccione R, Fernaud-Espinosa I, Robles V, Yuste R, DeFelipe J (2013) Age-based comparison of human dendritic spine structure using complete three-dimensional reconstructions. Cereb Cortex 23:1798-1810. https://doi.org/10.1093/cercor/bhs154

Brager DH, Johnston D (2014) Channelopathies and dendritic dysfunction in fragile X syndrome. Brain Res Bull 103:11-17. https://doi.org/10. 1016/j.brainresbull.2014.01.002

Cajal SRy (1917) Recuerdos de mi vida: historia de mi labor científica, vol 2. Moya, Madrid

Carr JL, Agnihotri S, Keightley M (2010) Sensory processing and adaptive behavior deficits of children across the fetal alcohol spectrum disorder continuum. Alcohol Clin Exp Res 34(6):1022-1032. https://doi.org/10.1111/j.1530-0277.2010.01177.x

Cauller L (1995) Layer I of primary sensory neocortex: where top-down converges upon bottom-up. Behav Brain Res 71(1):163-170. https:// doi.org/10.1016/0166-4328(95)00032-1

Cauller LJ, Clancy B, Connors BW (1998) Backward cortical projections to primary somatosensory cortex in rats extend long horizontal axons in layer I. J Comp Neurol 390(2):297-310

Cichon J, Gan WB (2015) Branch-specific dendritic $\mathrm{Ca}(2+)$ spikes cause persistent synaptic plasticity. Nature 520(7546):180-185. https://doi. org/10.1038/nature14251

Constantinople CM, Bruno RM (2013) Deep cortical layers are activated directly by thalamus. Science 340(6140):1591-1594. https://doi.org/ 10.1126/science. 1236425

Coogan TA, Burkhalter A (1990) Conserved patterns of cortico-cortical connections define areal hierarchy in rat visual cortex. Exp Brain Res 80(1):49-53. https://doi.org/10.1007/BF00228846

Davie JT, Kole MH, Letzkus JJ, Rancz EA, Spruston N, Stuart GJ, Häusser M (2006) Dendritic patch-clamp recording. Nat Protoc 1(3):12351247. https://doi.org/10.1038/nprot.2006.164

De Giorgio A, Granato A (2015) Reduced density of dendritic spines in pyramidal neurons of rats exposed to alcohol during early postnatal life. Int J Dev Neurosci 41:74-79. https://doi.org/10.1016/j.ijdev neu.2015.01.005

DeFelipe J, López-Cruz PL, Benavides-Piccione R, Bielza C, Larrañaga $P$, Anderson $S$ et al (2013) New insights into the classification and nomenclature of cortical GABAergic interneurons. Nat Rev Neurosci 14:202-216. https://doi.org/10.1038/nrn3444

Dierssen M, Ramakers GJ (2006) Dendritic pathology in mental retardation: from molecular genetics to neurobiology. Genes Brain Behav 5(Suppl 2):48-60. https://doi.org/10.1111/j.1601-183X. 2006.00224.x

Dierssen M, Fillat C, Crnic L, Arbonés M, Flórez J, Estivill X (2001) Murine models for Down syndrome. Physiol Behav 73(5):859871. https://doi.org/10.1016/s0031-9384(01)00523-6

Elston GN (2003) Cortex, cognition and the cell: new insights into the pyramidal neuron and prefrontal function. Cereb Cortex 13:11241138. https://doi.org/10.1093/cercor/bhg093

Elston GN (2007) Specializations in pyramidal cell structure during primate evolution. In: Kaas JH, Preuss TM (eds) Evolution of nervous systems. Academic Press, Oxford, pp 191-242

Elston GN, DeFelipe J (2002) Spine distribution in cortical pyramidal cells: a common organizational principle across species. Prog Brain Res 136:109-133. https://doi.org/10.1016/s0079-6123(02) 36012-6 
Elston GN, Fujita I (2014) Pyramidal cell development: postnatal spinogenesis, dendritic growth, axon growth, and electrophysiology. Front Neuroanat 8:78. https://doi.org/10.3389/fnana.2014.00078

Elston GN, Benavides-Piccione R, DeFelipe J (2001) The pyramidal cell in cognition: a comparative study in human and monkey. J Neurosci 21:RC163. https://doi.org/10.1523/JNEUROSCI.21-17-j0002.2001

Fry AE, Fawcett KA, Zelnik N, Yuan H, Thompson BAN et al (2018) De novo mutations in GRIN1 cause extensive bilateral polymicrogyria. Brain 141:698-712. https://doi.org/10.1093/brain/awx358

Goriounova NA, Heyer DB, Wilbers R, Verhoog MB, Giugliano M, Verbist C, Obermayer J, Kerkhofs A, Smeding H, Verberne M, Idema S, Baayen JC, Pieneman AW, de Kock CP, Klein M, Mansvelder HD (2018) Large and fast human pyramidal neurons associate with intelligence. Elife. https://doi.org/10.7554/eLife.41714

Gould E, Allan MD, McEwen BS (1990) Dendritic spine density of adult hippocampal pyramidal cells is sensitive to thyroid hormone. Brain Res 525(2):327-329. https://doi.org/10.1016/0006-8993(90)90884-e

Granato A (2006) Altered organization of cortical interneurons in rats exposed to ethanol during neonatal life. Brain Res 1069(1):23-30. https://doi.org/10.1016/j.brainres.2005.11.024

Granato A, De Giorgio A (2014) Alterations of neocortical pyramidal neurons: turning points in the genesis of mental retardation. Front Pediatr 2:86. https://doi.org/10.3389/fped.2014.00086

Granato A, Di Rocco F, Zumbo A, Toesca A, Giannetti S (2003) Organization of cortico-cortical associative projections in rats exposed to ethanol during early postnatal life. Brain Res Bull 60(4):339-344. https://doi.org/10.1016/S0361-9230(03)00052-2

Granato A, Palmer LM, De Giorgio A, Tavian D, Larkum ME (2012) Early exposure to alcohol leads to permanent impairment of dendritic excitability in neocortical pyramidal neurons. J Neurosci 32(4):1377-1382. https://doi.org/10.1523/JNEUROSCI.5520-11.2012

Guerguiev J, Lillicrap TP, Richards BA (2017) Towards deep learning with segregated dendrites. eLife 6:e22901. https://doi.org/10.7554/eLife. 22901

Hamilton GF, Whitcher LT, Klintsova AY (2010) Postnatal binge-like alcohol exposure decreases dendritic complexity while increasing the density of mature spines in $\mathrm{mPFC}$ Layer II/III pyramidal neurons. Synapse 64(2):127-135. https://doi.org/10.1002/syn.20711

Ipiña SL, Ruiz-Marcos A (1986) Dendritic structure alterations induced by hypothyroidism in pyramidal neurons of the rat visual cortex. Brain Res 394(1):61-67. https://doi.org/10.1016/0165-3806(86)90082-9

Jacobs B, Scheibel AB (2002) Regional dendritic variation in primate cortical pyramidal cells. In: Schüz A, Miller R (eds) Cortical areas: unity and diversity. Taylor and Francis, London, pp 111-131

Jiang YH, Armstrong D, Albrecht U, Atkins CM, Noebels JL, Eichele G, Sweatt JD, Beaudet AL (1998) Mutation of the Angelman ubiquitin ligase in mice causes increased cytoplasmic p53 and deficits of contextual learning and long-term potentiation. Neuron 21(4):799-811. https://doi.org/10.1016/s0896-6273(00)80596-6

Kampa BM, Letzkus JJ, Stuart GJ (2006) Requirement of dendritic calcium spikes for induction of spike-timing-dependent synaptic plasticity. J Physiol 574(Pt 1):283-290. https://doi.org/10.1113/jphysiol.2006. 111062

Karnani MM, Agetsuma M, Yuste R (2014) A blanket of inhibition: functional inferences from dense inhibitory connectivity. Curr Opin Neurobiol 26:96-102. https://doi.org/10.1016/j.conb.2013.12.015

Kaufmann WE, Moser HW (2000) Dendritic anomalies in disorders associated with mental retardation. Cereb Cortex 10(10):981-991. https:// doi.org/10.1093/cercor/10.10.981

Knafo S, Grossman Y, Barkai E, Benshalom G (2001) Olfactory learning is associated with increased spine density along apical dendrites of pyramidal neurons in the rat piriform cortex. Eur J Neurosci 13(3):633-638. https://doi.org/10.1046/j.1460-9568. 2001.01422.x

Krieger P, de Kock CPJ, Frick A (2017) Calcium dynamics in basal dendrites of layer $5 \mathrm{~A}$ and $5 \mathrm{~B}$ pyramidal neurons is tuned to the cell-type specific physiological action potential discharge. Front Cell Neurosci. https://doi.org/10.3389/fncel.2017.00194

LaBerge D (2006) Apical dendrite activity in cognition and consciousness. Conscious Cogn 15(2):235-257. https://doi.org/10.1016/j. concog.2005.09.007

Larkman AU (1991) Dendritic morphology of pyramidal neurones of the visual cortex of the rat: I. Branching patterns. J Comp Neurol 306(2):307-319. https://doi.org/10.1002/cne.903060207

Larkum M (2013) A cellular mechanism for cortical associations: an organizing principle for the cerebral cortex. Trends Neurosci 36(3):141-151. https://doi.org/10.1016/j.tins.2012.11.006

Larkum ME, Zhu JJ, Sakmann B (1999) A new cellular mechanism for coupling inputs arriving at different cortical layers. Nature 398(6725):338-341. https://doi.org/10.1038/18686

Larkum ME, Nevian T, Sandler M, Polsky A, Schiller J (2009) Synaptic integration in tuft dendrites of layer 5 pyramidal neurons: a new unifying principle. Science 325(5941):756-760. https://doi. org/10.1126/science.1171958

Lemke JR, Geider K, Helbig KL, Heyne HO, Schütz H et al (2016) Delineating the GRIN1 phenotypic spectrum: a distinct genetic NMDA receptor encephalopathy. Neurology 86:2171-2178. https://doi.org/10.1212/WNL.0000000000002740

Lübke J, Feldmeyer D (2007) Excitatory signal flow and connectivity in a cortical column: focus on barrel cortex. Brain Struct Funct 212(1):3-17. https://doi.org/10.1007/s00429-007-0144-2

Luebke JI (2017) Pyramidal neurons are not generalizable building blocks of cortical networks. Front Neuroanat 11:11. https://doi. org/10.3389/fnana.2017.00011

Mainen ZF, Sejnowski TJ (1996) Influence of dendritic structure on firing pattern in model neocortical neurons. Nature 382(6589):363366. https://doi.org/10.1038/382363a0

Mäki-Marttunen T, Devor A, Phillips WA, Dale AM, Andreassen OA, Einevoll GT (2019) Computational modeling of genetic contributions to excitability and neural coding in layer V pyramidal cells: applications to schizophrenia pathology. Front Comput Neurosci 13:66-66. https://doi.org/10.3389/fncom.2019.00066

Marini C, Porro A, Rastetter A, Dalle C, Rivolta I, Bauer D, Oegema R, Nava C, Parrini E, Mei D, Mercer C, Dhamija R, Chambers C, Coubes C, Thévenon J, Kuentz P, Julia S, Pasquier L, Dubourg C, Carré W, Rosati A, Melani F, Pisano T, Giardino M, Innes AM, Alembik Y, Scheidecker S, Santos M, Figueiroa S, Garrido C, Fusco C, Frattini D, Spagnoli C, Binda A, Granata T, Ragona F, Freri E, Franceschetti S, Canafoglia L, Castellotti B, Gellera C, Milanesi R, Mancardi MM, Clark DR, Kok F, Helbig KL, Ichikawa S, Sadler L, Neupauerová J, Laššuthova P, Šterbová K, Laridon A, Brilstra E, Koeleman B, Lemke JR, Zara F, Striano P, Soblet J, Smits G, Deconinck N, Barbuti A, DiFrancesco D, LeGuern E, Guerrini R, Santoro B, Hamacher K, Thiel G, Moroni A, DiFrancesco JC, Depienne C (2018) HCN1 mutation spectrum: from neonatal epileptic encephalopathy to benign generalized epilepsy and beyond. Brain 141(11):3160-3178. https://doi.org/10. 1093/brain/awy263

Markram H, Toledo-Rodriguez M, Wang Y, Gupta A, Silberberg G, Wu C (2004) Interneurons of the neocortical inhibitory system. Nat Rev Neurosci 5:793-807. https://doi.org/10.1038/nrn1519

Meredith RM, Holmgren CD, Weidum M, Burnashev N, Mansvelder HD (2007) Increased threshold for spike-timing-dependent plasticity is caused by unreliable calcium signaling in mice lacking fragile X gene FMR1. Neuron 54(4):627-638. https://doi.org/10. 1016/j.neuron.2007.04.028

Meyer HS, Wimmer VC, Hemberger M, Bruno RM, de Kock CPJ, Frick A, Sakmann B, Helmstaedter M (2010) Cell type-specific thalamic innervation in a column of rat vibrissal cortex. Cereb Cortex (New York, NY : 1991) 20(10):2287-2303. https://doi. org/10.1093/cercor/bhq069 
Miao S, Chen R, Ye J, Tan GH, Li S, Zhang J, Jiang YH, Xiong ZQ (2013) The Angelman syndrome protein Ube3a is required for polarized dendrite morphogenesis in pyramidal neurons. J Neurosci 33(1):327-333. https://doi.org/10.1523/jneurosci.2509-12. 2013

Murray G, McKenzie K, Murray A, Whelan K, Cossar J, Murray K, Scotland J (2019) The impact of contextual information on the emotion recognition of children with an intellectual disability. J Appl Res Intellect Disabil 32(1):152-158. https://doi.org/10. 1111/jar. 12517

Nevian T, Larkum ME, Polsky A, Schiller J (2007) Properties of basal dendrites of layer 5 pyramidal neurons: a direct patch-clamp recording study. Nat Neurosci 10(2):206-214. https://doi.org/10. 1038/nn1826

Nolan MF, Malleret G, Dudman JT, Buhl DL, Santoro B, Gibbs E, Vronskaya S, Buzsáki G, Siegelbaum SA, Kandel A, Morozov A (2004) A behavioral role for dendritic integration: HCN1 channels constrain spatial memory and plasticity at inputs to distal dendrites of CA1 pyramidal neurons. Cell 119:719-732. https:// doi.org/10.1016/j.cell.2004.11.020

Palmer LM (2014) Dendritic integration in pyramidal neurons during network activity and disease. Brain Res Bull 103:2-10. https:// doi.org/10.1016/j.brainresbull.2013.09.010

Palmer L, Murayama M, Larkum M (2012) Inhibitory regulation of dendritic activity in vivo. Front Neural Circuits. https://doi.org/ 10.3389/fncir.2012.00026

Pérez-Cremades D, Hernández S, Blasco-Ibáñez JM, Crespo C, Nacher J, Varea E (2010) Alteration of inhibitory circuits in the somatosensory cortex of Ts65Dn mice, a model for Down's syndrome. J Neural Transm (Vienna) 117(4):445-455. https://doi.org/10. 1007/s00702-010-0376-9

Perez-Cruz C, Nolte MW, van Gaalen MM, Rustay NR, Termont A, Tanghe A, Kirchhoff F, Ebert U (2011) Reduced spine density in specific regions of CA1 pyramidal neurons in two transgenic mouse models of Alzheimer's disease. J Neurosci 31(10):39263934. https://doi.org/10.1523/jneurosci.6142-10.2011

Phillips WA (2017) Cognitive functions of intracellular mechanisms for contextual amplification. Brain Cogn 112:39-53. https://doi. org/10.1016/j.bandc.2015.09.005

Phillips WA, Larkum ME, Harley CW, Silverstein SM (2016) The effects of arousal on apical amplification and conscious state. Neurosci Conscious 1:niw015-niw015. https://doi.org/10.1093/ nc/niw015

Pi HJ, Hangya B, Kvitsiani D, Sanders JI, Huang ZJ, Kepecs A (2013) Cortical interneurons that specialize in disinhibitory control. Nature 503(7477):521-524. https://doi.org/10.1038/nature12676

Quach TT, Stratton HJ, Khanna R, Kolattukudy PE, Honnorat J, Meyer K, Duchemin AM (2021) Intellectual disability: dendritic anomalies and emerging genetic perspectives. Acta Neuropathol 141(2):139-158. https://doi.org/10.1007/s00401-020-02244-5

Ramaswamy S, Markram H (2015) Anatomy and physiology of the thick-tufted layer 5 pyramidal neuron. Front Cell Neurosci. https:// doi.org/10.3389/fncel.2015.00233

Sala C, Segal M (2014) Dendritic spines: the locus of structural and functional plasticity. Physiol Rev 94(1):141-188. https://doi.org/ 10.1152/physrev.00012.2013

Sceniak MP, Fedder KN, Wang Q, Droubi S, Babcock K, Patwardhan S, Wright-Zornes J, Pham L, Sabo SL (2019) An autism-associated mutation in GluN2B prevents NMDA receptor trafficking and interferes with dendrite growth. J Cell Sci 132:jcs232892

Shepherd GMG (2013) Corticostriatal connectivity and its role in disease. Nat Rev Neurosci 14(4):278-291. https://doi.org/10.1038/ $\operatorname{nrn} 3469$
Sherman SL, Allen EG, Bean LH, Freeman SB (2007) Epidemiology of Down syndrome. Ment Retard Dev Disabil Res Rev 13(3):221227. https://doi.org/10.1002/mrdd.20157

Shin W, Kim K, Serraz B, Cho YS, Kim D, Kang M, Lee E, Lee H, Bae YC, Paoletti P, Kim E (2020) Early correction of synaptic long-term depression improves abnormal anxiety-like behavior in adult GluN2B-C456Y-mutant mice. PLoS Biol 18:e3000717. https://doi.org/10.1371/journal.pbio.3000717

Shogren KA, Turnbull HR (2010) Public policy and outcomes for persons with intellectual disability: extending and expanding the public policy framework of AAIDD's 11th edition of intellectual disability: definition, classification, and systems of support. Intellect Dev Disabil 48(5):375-386. https://doi.org/10.1352/ 1934-9556-48.5.375

Spratt PWE, Ben-Shalom R, Keeshen CM, Burke KJ Jr, Clarkson RL, Sanders SJ, Bender KJ (2019) The autism-associated gene Scn2a contributes to dendritic excitability and synaptic function in the prefrontal cortex. Neuron 103(4):673-685.e675. https://doi.org/ 10.1016/j.neuron.2019.05.037

Spruston N (2008) Pyramidal neurons: dendritic structure and synaptic integration. Nat Rev Neurosci 9(3):206-221. https://doi.org/10. 1038/nrn2286

Stuart GJ, Sakmann B (1994) Active propagation of somatic action potentials into neocortical pyramidal cell dendrites. Nature 367(6458):69-72. https://doi.org/10.1038/367069a0

Suetsugu M, Mehraein P (1980) Spine distribution along the apical dendrites of the pyramidal neurons in Down's syndrome: a quantitative golgi study. Acta Neuropathol 50(3):207-210. https://doi. org/10.1007/bf00688755

Takahashi N, Ebner C, Sigl-Glöckner J, Moberg S, Nierwetberg S, Larkum ME (2020) Active dendritic currents gate descending cortical outputs in perception. Nat Neurosci 23(10):1277-1285. https://doi.org/10.1038/s41593-020-0677-8

Thomazeau A, Lassalle O, Iafrati J, Souchet B, Guedj F, Janel N, Chavis P, Delabar J, Manzoni OJ (2014) Prefrontal deficits in a murine model overexpressing the down syndrome candidate gene dyrk1a. J Neurosci 34(4):1138-1147. https://doi.org/10.1523/ jneurosci.2852-13.2014

Thomson A (2010) Neocortical layer 6: a review. Front Neuroanat. https://doi.org/10.3389/fnana.2010.00013

Thomson AM, Morris OT (2002) Selectivity in the inter-laminar connections made by neocortical neurones. J Neurocytol 31(3):239246. https://doi.org/10.1023/A:1024117908539

Valenzuela CF, Morton RA, Diaz MR, Topper L (2012) Does moderate drinking harm the fetal brain? Insights from animal models. Trends Neurosci 35(5):284-292. https://doi.org/10.1016/j.tins. 2012.01.006

Vieira MM, Jeong J, Roche KW (2021) The role of NMDA receptor and neuroligin rare variants in synaptic dysfunction underlying neurodevelopmental disorders. Curr Opin Neurobiol 69:93-104. https://doi.org/10.1016/j.conb.2021.03.001

Whitcher LT, Klintsova AY (2008) Postnatal binge-like alcohol exposure reduces spine density without affecting dendritic morphology in rat mPFC. Synapse 62(8):566-573. https://doi.org/10.1002/syn. 20532

Yuste R (2011) Dendritic spines and distributed circuits. Neuron 71(5):772-781. https://doi.org/10.1016/j.neuron.2011.07.024

Publisher's Note Springer Nature remains neutral with regard to jurisdictional claims in published maps and institutional affiliations. 